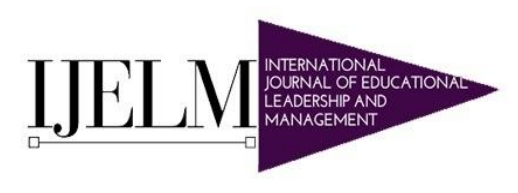

Hipatia Press

www.hipatiapress.com

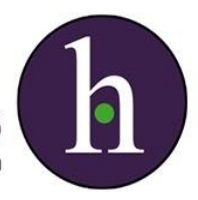

Instructions for authors, subscriptions and further details:

http://ijelm.hipatiapress.com

\title{
A study on Ethical leadership perceptions and its impact on teachers commitment in Pakistan
}

\section{Sara Sabir ${ }^{1}$}

1) University of Education, Multan, Pakistan.

Date of publication: January $16^{\text {th }}, 2021$

Edition period: July 2020 - January 2021

To cite this article: Sabir, S. (2021). A study on Ethical leadership perceptions and its impact on teachers commitment in Pakistan. International Journal of Educational Leadership and Management. doi: 10.17583/ijelm.2021.4525

To link this article: http://dx.doi.org/10.17583/ijelm.2021.4525

\section{PLEASE SCROLL DOWN FOR ARTICLE}

The terms and conditions of use are related to the Open Journal System and to Creative Commons Attribution License(CCAL). 


\title{
A study on Ethical leadership perceptions and its impact on teachers commitment in Pakistan
}

\author{
Sara Sabir \\ University of Education, Multan \\ Pakistan
}

\section{Abstract}

The primary objective of this research article is to study the concept of ethical leadership by determining the perceptions of school teachers regarding ethical leadership behaviors of the school leaders and establishing its relation with teacher's commitment. In addition, this study tests the validity of ELQ survey instrument in educational sector of Pakistan. The research has collected data from a random sample of schools in the two largest districts of Punjab in Pakistan. The empirical study is based on primary data collected from 320 teachers and the results of this study reveal that the teachers perceived their leaders to be moderately ethical and a significant positive relationship existed between the two. Also, age and gender of employees did not affect the ethical leadership behaviors, however seniority of the employee had an impact on the ethical leadership behavior perceptions. Also, Ethical leadership was also found to positively impact on the two out of four dimensions of the teacher commitment, which are commitment to teaching and commitment to profession. This study adds contribution to theory by investigating the relationship between ethical leadership behaviors and the organizational commitment by conceptualizing it as teacher commitment. The practical implication of this study is that effective ethical leadership behavior that drives employee commitment need to be fostered in organizations to drive efficient performance.

Keywords: Ethical leadership, teacher commitment, school leaders, school teachers. 


\title{
Estudio sobre las percepciones de liderazgo ético y su impacto en el compromiso de los docentes en Pakistán
}

\author{
Sara Sabir \\ University of Education, Multan \\ Pakistan
}

\section{Resumen}

El objetivo principal de este artículoes estudiar el concepto de liderazgo ético determinando las percepciones de los maestros de escuela con respecto a los comportamientos de liderazgo ético de los líderes escolares y estableciendo su relación con el compromiso del maestro. Además, este estudio prueba la validez del instrumento de encuesta ELQ en el sector educativo de Pakistán. La investigación ha recopilado datos de una muestra aleatoria de escuelas en los dos distritos más grandes de Punjab en Pakistán. El estudio empírico se basa en datos primarios recopilados de 320 docentes y los resultados de este estudio revelan que los docentes percibieron que sus líderes eran moderadamente éticos y que existía una relación positiva significativa entre los dos. Además, la edad y el género de los empleados no afectaron los comportamientos de liderazgo ético, sin embargo, la antigüedad del empleado tuvo un impacto en las percepciones de comportamiento de liderazgo ético. Además, también se descubrió que el liderazgo ético tiene un impacto positivo en las dos dimensiones del compromiso del maestro, que son el compromiso con la enseñanza y el compromiso con la profesión. Este estudio agrega contribución a la teoría al investigar la relación entre los comportamientos éticos de liderazgo y el compromiso organizacional al conceptualizarlo como el compromiso del maestro. La implicación práctica de este estudio es que el comportamiento de liderazgo ético efectivo que impulsa el compromiso de los empleados debe fomentarse en las organizaciones para impulsar un rendimiento eficiente.

Palabras clave: Liderazgo ético, compromiso docente, líderes escolares, docentes escolares.

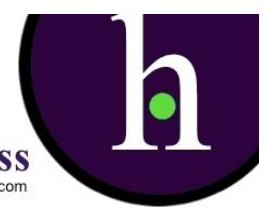


oday'sdynamic environment has posed challenges for the organizations and leaders are charged with more duties and _esponsibilities owing to changing technology and globalization. The last century has undergone a radical shift regarding the role of leadership. In the past, leaders were considered to be super humans possessing extraordinary powers to motivate workers and keep them committed. However, the 21 st century marks the implications of ethical and moral virtues as foundation of leadership which emphasizes more on the 'means' than the 'ends'. Acting in a just and responsible manner can lead to protection of organizational interest more than self- interest of its members, consequently promoting the overall welfare and stability of society (Özan, Özdemir, \&Yirci, 2017).

The popular approaches to leadership include situational and behavioral theories, in which leadership is defined in terms of certain situations and behaviors respectively. Ethical leadership is a relatively modern and now a prominent approach in which a leadership style is defined under an ethical umbrella (Ko, Ma, Bartnik, Haney, \& Kang, 2018). When leaders in any profession or any organization deal within the boundaries of ethical codes, they can win trust and commitment of their workers. Hence, Özan et al., (2017) suggest that an ethical leader can influence his followers to the point where they can achieve goals for instance, commitment. According to James Mac Gregor Burns,

"Divorced from ethics, leadership is reduced to management and politics to mere technique."

The debate about ethics in educational sector has gained popularity recently due to the importance of employing ethical behavior at school by leaders when making decisions regarding ethical work issues and that the next generation learns ethical and moral standards from these leaders (Haynes, 2002) as per the Social Learning theory (Bandura \& Walters, 1977). While fulfilling the responsibilities in a school, being a social organization, the leaders have to interact with many people like students, teachers, parents and other staff members. As a result of these interactions, 
many times situations may arise that involve decision- making without conflicting with ethical standards (Daniëls, Hondeghem, \&Dochy, 2019). School is the best place where its members can apply ethical principles in their dealings. Ethical school leaders have three responsibilities. Firstly, they have responsibility towards themselves in sticking to the ethical principals more than any. Secondly, they have responsibility towards the school in enforcing the ethical rules and thirdly, the fulfillment of social responsibility by introduction of these principles to the school community (Celik, 2000).

Bai, Lin, \& Liu(2019),Kim \& Thapa(2018) Ko et al.,(2018) andÖzan et al.,(2017)proposed to check the generalizability of the result from their research regarding ethical leadership in nations other than Korea and Turkey respectively. Similarly, Hassan, Mahsud, Yukl, \& Prussia (2013), Kalshoven\& Boon (2012), Yukl, Mahsud, Hassan, \& Prussia (2013) highlighted the need to expand or replicate findings on relationship of ethical leadership with various outcome constructs and also see whether ELQ shows consistent results in different setups and in different countries. Based on these gaps in literature, the main objective of this paper is to determine the extent of ethical leadership behavior perceptions from the stand point of teachers, to prove the validity of ELQ survey instrument in educational sector of Pakistan and to examine the relationship between ethical leadership and teacher commitment. Moreover, this study attempts to seek answer to the following research questions:

- Is the ELQ scale valid for education sector in Pakistan?

- What is the perception of teachers regarding ethical leadership in schools?

- What is the relationship between ethical leadership and commitment of teachers in schools?

- How does ethical leadership affect the individual dimensions of teacher commitment? 


\section{Literature Review}

\section{Ethical Leadership}

Generally speaking, leadership is the power of an individual to influence other people. However, using the notion of ethics, leadership is defined as "the power to determine what is good and bad or what is right and wrong to achieve common goals" (Bolat\&Seymen, 2003). This implies that "ethical leaders lay down rules, follow these rules and seek to enforce them". The domain of ethical leadership is broad in nature, encompassing altruism, trust $\&$ integrity, fairness in rewards distribution, honesty in dealings, being supportive, engaging in open \& transparent communication, emphasizing ethical values, setting clear ethical standards and holding those accountable for indulging in unethical practices (Yukl et al., 2013). Although a popular field, Ethical Leadership as a construct has suffered disintegration and confusion regarding its exact philosophy. The Center for Ethical Leadership state that "Ethical leadership is about knowing your core values and having the courage to live them in all parts of your life in service of the common good" (Grace \& Grace, 1998). The management perspective views ethical leadership as "the demonstration of normatively appropriate conduct through personal actions and interpersonal relationships, and the promotion of such conduct to followers through two-way communication, reinforcement, and decision-making". Using this perspective, "a leader as a moral manager is one "who discuss ethical norms or standards with subordinates and offer proper punishments and rewards with regards to ethical/unethical behaviors), and a moral person (i.e., a caring, honest, and principled individual who makes balanced decisions)" (Brown \& Treviño, 2006). They also developed a 10-item scale to measure perceptions of ethical leadership known as the Ethical Leadership Scale (ELS).

De Hoogh\& Den Hartog (2008) defined ethical leadership as "a set of behaviors or a separate leadership style in itself rather than focusing only on the ethical components of other leadership styles. Kanungo \& Mendonca (2001)conceptualized ethical leadership with an altruism approach and defined it as "a tension between altruistic and egoistic motives. This 
approach shows that an ethical leader prioritizes a set of widely accepted beliefs and proper judgments over self-interest, which can prove beneficial for followers and the organization. Ethical leadership has been found to be linked to the characteristic traits of a leader like honesty, trustworthiness and integrity and ethical behaviors like openness, fairness, concern and ethical decision- making (Treviño, Brown, \& Hartman, 2003). Hence, an ethical leader can be considered as a "moral person" by his/ her followers and as a "moral manager", in that his/ her morality influences employees to the extent that they engage in positive work behaviors (Ko et al., 2018). Broadly speaking, ethical leader is "moral person who manifests moral traits and behaviors in their personal lives". Not only do the ethical leaders have these special qualities, but they also are indulged in moral management" by which they actively influence their workers to be serious and careful of their ethics and encourages them to act ethically and morally. A leader can ignite these values in followers by effectively communicating them or by role modeling these values (Brown \& Treviño, 2006; Ko et al., 2018).

Early researchers have based their understanding of the concept of ethical behavior on two theories: namely Social Learning Theory (Bandura \& Walters, 1977) and the Social Exchange Theory (Blau, 1964). The social learning theory has been used by the researchers working on leadership approaches about how ethical leaders can act and serve as role models to attract their followers' attention towards enforcing ethical standards and engaging in ethical practices in their decision- making. This way an environment of ethical behavior can be created in an organization. There is a dual approach to this. First, ethical leaders impact their followers by their actions as a role model and then secondly, followers learn this behavior from leader by observing and taking note of the compensation and punishments offered by the leader in lieu to it (Bai et al., 2019).

On the other hand, the believers of Social exchange theory state that ethical leaders and followers engage in "transactional exchange", i.e., it is a contract-like relationship in which the leaders demonstrate fairness and caring for their workers and the workers as being obligated by this act of kindness return this gesture with positive behavior at work. This is a norm of reciprocity in which the followers act according to the expectations of their 
leaders (Blau, 1964). Mayer, Kuenzi, Greenbaum, Bardes, \& Salvador (2009), Simola, Barling, \& Turner (2012) used a social exchange approach perspective to explain ethical leadership. They claim that when the workers are treated ethically and fairly, they tend to reciprocate in the form of positive work behavior that can lead towards goal achievement. There is a prominent difference between various leadership styles like transformational leadership, transactional leadership, authentic leadership, servant leadership and spiritual leadership and ethical leadership, which serves as a distinct construct, both on the empirical and the conceptual level. Ethical leadership has its foundation on the ethical and moral standards and hence, moral management. In contrast to this, transformational leadership is one that focuses on values, goals, organizational culture and intellectual stimulation for the achievement of these goals (Bedi, Alpaslan, \& Green, 2016).

The main characteristic that ethical leadership is identified and serves distinct from other prominent leadership styles is essentially the use of moral values in their management. Ethical leaders tend to adopt the transactional aspect of moral management. This promotes the "others" awareness more than "self-interest", as opposed to the authentic leadership style. Even the way spiritual leaders focus on the hopes, faith and vision is different from that of an ethical leader (Bedi et al., 2016). However, it is important to note that although there is a significant difference among these styles, these overlap. For instance, all leadership styles have the tendency to influence the employee behavior (Brown \&Treviño, 2006). Bedi et al., (2016) conducted a meta- analysis that suggested that empirically there is a strong association between ethical leadership, transformational leadership and the related reward dimensions of transactional leadership. So, this proves that there exists a partial overlap in these approaches. This is in accordance with the previous empirical and conceptual contributions made by previous researchers like (Riggio, Zhu, Reina, \&Maroosis, 2010; Shao, 2010). They argued that one or another aspect of leadership styles like consideration and inspirational motivation are common. Ethical leaders influence their followers through role modeling, integrity and ethical decision- making and so does a transformational leader, who may use collective motivation and empowerment (Bedi et al., 2016). Bedi et al., (2016) also put forward that 
although transformational leadership possesses a few aspects that cannot be taken as a part of ethical leadership but the "boundary between the two is blurred". A significant point of this study's discussion is that what precisely are these ethical and moral rules specifically in the field of education and what are the traits linked to ethical leaders and how are they applied in the school environment? Regarding this, George Marshall proposed eight guiding principles of ethical leadership for school leaders on the implementation of ethical practices in the educational institutions. When school leaders consider these principles in their dealings, the chances of success within school environment increase (Lynch, 2015).

1. Personal Courage: With the aim of creating a positive educational environment, the school leaders must have the courage to stand up against those policies which might not seem helpful for the students (Lynch, 2015).

2. Public Interest Ahead of Self: the interest and needs of the school community, including both students and staff, must precede self- interests of the leader himself (Lynch, 2015)

3. Self Control, Self Discipline and Integrity: it is vital for the leader to possess these three traits and be a positive role model. The relationships between leaders and his/ her followers must not only rely on trust, but on respect and ethical actions (Lynch, 2015).

4. Task and Employee Centeredness: While making decisions, the school leaders must take into account the needs of students and staff and a unity need to be created among the two groups (Lynch, 2015).

5. Recognizing Talent: An ethical leader must recognize and acknowledge the talent of their followers through identification, right placement and promotion to create goodwill among all school members (Lynch, 2015).

6. Requiring High Ethics from Everyone: School leaders must take care to follow and enforce ethical standards of all in their school after clearly communicating them (Lynch, 2015). 
7. Sensitivity and Understanding: In order to ensure equity among the school members, sensitivity and understanding of educational and institutional policies is necessary (Lynch, 2015).

8. Inclusiveness: this means that all the stakeholders must be involved in the decision- making and implementing process. This can serves as a key driver of building trust within the school which can boost follower's motivation and lift morale. Hence, overall effectiveness of school is increased (Lynch, 2015).

Ethical standards for school leaders are practiced in countries like Australia, Canada and the USA. These standards require employees working for the cause of education should fulfill this responsibility fairly, consistently, honestly and impartially. When everyone in school acts according to ethical principles schools become peaceful workplaces (Campbell, Kyriakides, Muijs, \& Robinson, 2004). Since ethical leadership has been in the topic of interest of many researchers since decades (Tarter, 1989), it was important to devise a reliable and valid instrument to measure the ethical leadership behaviors. The first attempt for this was done by (Brown \&Treviño, 2006) who developed the ELS (Ethical Leadership scale) in top- management teams and used this to test the relationship between ethical leadership and many other outcome variables. Secondly, De Hoogh\& Den Hartog, (2008) used three scales from the Multi-Culture Leader Behavior Questionnaire (Resick, Hanges, Dickson, \&Mitchelson, 2006) in order to investigate how ethical leadership can contribute to leader effectiveness and optimism of subordinates. Thirdly, Kalshoven, Den Hartog, \& De Hoogh(2011) proposed ELW (Ethical Leadership at Work) Questionnaire with 38 items and 7 sub-scales. This is a multidimensional scale to measure the ethical leadership with ethical leader behaviors like power sharing, fairness, role clarification, integrity, people orientation, sustainability and ethical guidance. This is a widely used and accepted scale of ethical leadership in empirical studies. Next, Yukl et al., (2013) also developed ELQ instrument with 15 items and each item on a 6-point Likert scale. These items include ethical leadership aspects like "integrity, honesty, 
altruism, integrity and consistency of behavior with espoused values, communication of ethical values, and providing ethical guidance".

\section{Teacher Commitment}

The dynamics of today's employment have stressed on the importance of committed employees leading to overall organizational well- being (Hendri, 2019).Organizational commitment was first introduced by Becker using the concept of "side-bets", "i.e., all tangible and intangible investments (e.g., efforts, time, relationships) the employees make in the time they spend in a particular organization" (Powell \& Meyer, 2004). Meyer \& Allen (1984), Porter, Mowday, \& Steers (1979) defined Organizational commitment as "the attitude of an individual toward the organization it works for is organizational commitment" (Porter et al., 1979). Later, the most widely accepted model for organizational commitment was given by Meyer \& Allen (1984) who conceptualized it as being multi-dimensional, which are:

1. "Affective Commitment: (the desired mind-set) is the extent to which employees feel emotionally attached and involved in the organization,

2. Continuance Commitment: (the perceived cost mind-set) is the need to stay with the organization due to costs associated with leaving the organization, and

3. Normative Commitment: (the obligation mind-set) is based on the sense of obligation to remain in the particular organization" (Meyer \& Allen, 1984).

Allen \& Meyer (1996) showed that committed workers with high level of commitment have positive links to favorable employee outcomes. Same is the case with the organizational commitment held by school teachers (Thien, Razak, \&Ramayah, 2014).It is pertinent to note that the literature on teacher's commitment starts from the concept of organizational commitment and teachers commitment is equivalent to organizational commitment (Louis, 1998; Tsui\& Cheng, 1999) since teachers are the employees of school, being an organization (Sabir \& Bhutta, 2018). However, Allen and Meyer Model ignore some significant aspects of teaching profession. Hence, an extension for the model of organizational commitment specifically for 
teachers is necessary (Sabir \& Bhutta, 2018). Tsui\& Cheng (1999) state that"a committed teacher is one who links their identity with the school, has willingness to exert extra efforts for the school and accepts the school goals as their own".

Since teaching is composed of unique relationships among teachers, students and school community, the construct of teacher commitment encompasses dimensions, like Commitment to Teaching, Commitment to School, Commitment to Students and Commitment to Teaching Field by Singh \& Billingsley (1998) and Commitment to School, Academic Goals, Students and to body of knowledge by Louis (1998). Similar works were done by Celep (2000), Nir (2002), Somech\&Bogler (2002) in operationalizing Teacher Commitment into multi dimensions. Crosswell(2006) proposed six categories of Teacher Commitment which represent the phenomenon of Teacher Commitment as a whole and what actually teachers mean by "Teacher Commitment". They are:

- "Teacher commitment is passion for a certain aspect of teaching and the teachers see it as a motivating or a sustaining factor"

- "Teacher commitment is an investment of extra time, which is the time donated other than the usual contact hours with the students"

- "Teacher commitment is focus on the individual needs, both socioemotional and academic, of the students".

- "Teacher commitment is maintaining professional knowledge and quest for further professional learning"

- "Teacher commitment is taking responsibility for transmitting knowledge and attitudes, values and beliefs to prepare students to take responsibility for future endeavors".

- "Teacher commitment is the willingness to engage with the school and its community members and to stay working at a particular school as an organization" (Crosswell, 2006).

Thien et al., (2014) conceptualized Teacher Commitment into interrelated multi- dimensions that are important to improve the behavioral attitude of teachers over time and can be used to measure overall teacher 
commitment on a reliable and valid scale developed by them. They are: Commitment to Students, Commitment to Teaching, Commitment to School, and Commitment to Profession.

1. Teacher Commitment to Teaching: This is related to the psychological link between teachers and the teaching work. This can be checked by seeing the willingness of the teachers in exerting significant efforts in to be engaged in teaching and in devoting extra time for the students for improved results.

2. Teacher Commitment to Students: This is related to the involvement and responsibility assumed by teachers in student development and achievement by making learning meaningful.

3. Teacher commitment to School: This is related to the teachers believing and accepting the goals and values of school and they keep on working with the school for the achievement of these goals.

4. Teacher Commitment to Profession: This is related to the extent of motivation the teacher has to develop and progress into teaching knowledge and profession (Thien et al., 2014).

Table 1. Conceptualization and Operationalization of Teachers Commitment

\begin{tabular}{|l|l|l|}
\hline Dimensions & Conceptualization & Operationalization \\
\hline CommitmenttoStudents & $\begin{array}{l}\text { Teachers'involvement or } \\
\text { responsibility in student } \\
\text { learning }\end{array}$ & $\begin{array}{l}\text { The extent to which teachers } \\
\text { are involved in student } \\
\text { learning }\end{array}$ \\
\hline CommitmenttoTeaching & $\begin{array}{l}\text { Teachers'willingness to be } \\
\text { engaged in teaching work }\end{array}$ & $\begin{array}{l}\text { The degree to which teachers } \\
\text { want to be engaged in teaching } \\
\text { work }\end{array}$ \\
\hline CommitmenttoSchool & $\begin{array}{l}\text { Teachers' belief and } \\
\text { acceptance of the goals and } \\
\text { values of the school, } \\
\text { teachers' effort for } \\
\text { actualization of those goals } \\
\text { and values, and teachers' } \\
\text { strong desires to keep up } \\
\text { membership in theschool }\end{array}$ & $\begin{array}{l}\text { The extent to which teachers } \\
\text { bentirt by accepting the goals } \\
\text { and values of the school. }\end{array}$ \\
\hline
\end{tabular}


Sabir-Ethical leadership perceptions and its impact on teachers commitment

\begin{tabular}{|l|l|l|}
\hline $\begin{array}{l}\text { Commitmentto } \\
\text { Profession }\end{array}$ & $\begin{array}{l}\text { Teacher attitude, loyalty, and } \\
\text { involvement to enhance and } \\
\text { develop the profession they } \\
\text { have chosen. }\end{array}$ & $\begin{array}{l}\text { To what extent teachers are } \\
\text { able to enhance their teaching } \\
\text { profession. }\end{array}$ \\
\hline
\end{tabular}

Source: Thein et al., 2004

\section{Relationship between ethical leadership and teacher commitment}

According to Ko et al., (2018), ethical leaders are a role model for their workers since they can learn by paying attention to their leader and imitating their values and attitudes to inculcate in them an expected behavior. Hence, a leader has the power to influence and make the employees engage in favorablebehaviors. This shows that a leader can build a relationship with their workers and forge feelings of commitment in them by their ethical leadership style (Crosswell, 2006). Empirically in previous research works, ethical leadership has shown to be positively linked to organizational performance (Kim \& Thapa, 2018), Leader- member exchange \& managerial effectiveness (Yukl et al., 2013), leader effectiveness, job \& leader satisfaction, employee effectiveness and organizational citizenship behavior (Kalshoven\& Boon, 2012; Kalshoven et al., 2011). Further, ethical leadership has also shown significant positive relations with employee commitment (Agha, Nwekpa, \&Eze, 2017; Asif, Qing, Hwang, \& Shi, 2019; Byza, Dörr, Schuh, \& Maier, 2019; Qing, Asif, Hussain, \& Jameel, 2019). On the basis of these, the relationship between Ethical leadership and teacher commitment as a whole and its relationship with the individual dimensions of teacher commitment are evaluated. The following hypotheses were formulated.

H1: Ethical leadership has positive relationship with teacher commitment

$\mathrm{H} 2$ : Ethical leadership has positive relationship with commitment to students.

H3: Ethical leadership has positive relationship with commitment to teaching

H4: Ethical leadership has positive relationship with commitment to school

H5: Ethical leadership has positive relationship with commitment to profession. 


\section{Reserch methodology}

\section{Sample}

The participants for this study comprised of 320 teachers who were selected from a random sample of the schools situated in two of the largest district in Punjab, Pakistan.

\section{Procedure}

The data is collection with survey method using a cover letter describing the purpose of the research and a structured questionnaire as the research tool. While distributing the questionnaire, it was ensured to the teachers about with complete anonymity of identity and confidentiality of responses. The complete packet comprising of the letter and the questionnaire was administered to 300 teachers by the researcher. Out of these, a total of 306 filled questionnaires were returned back, so the response rate was almost $\%$. The questionnaires were checked for their missing values and the outliers. Using Mahalonobis distance tool, the outliers were treated and a total of 300 questionnaires were considered fit for the analysis.

\section{Survey Instrument}

The instrument used in this study to measure the ethical leadership perceptions is 15- items Ethical leadership at work (ELQ) scale developed and validated by (Yukl et al., 2013). For measuring teacher commitment, 14items scale developed and validated by Thien et al., (2014) was used. These instruments required respondents to answer on a likert scale ranging from 1 to 5 (1= Strongly Disagree, 2= Disagree, 3= Neutral, 4= Agree, 5= Strongly Agree). For measuring the individual dimensions of teacher commitment, the same scale was used in which commitment to school was measured with first 3 questions, the commitment to students was measured with the next 3 questions. The next 3 questions of the scale measured commitment to teaching, while the last 4 questions measured commitment to profession. 
The values of Cronbach's alpha for the scales of ELQ and Teacher Commitment were calculated to be 0.927 and 0.808 respectively, which shows that both scales are highly reliable.

\section{Analysis}

The preliminary analyses included the profile of the respondents, the descriptive statistics, correlations coefficient and Cronbach's alpha reliability were estimated using SPSS version 22. For running CFA and assessing the measurement model, AMOS version 22 was used. For checking that the data does not suffer from CMB (common method bias),Harman's one factor test was done. For this, the results of the EFA showed that using all the items of the variables, no single factor structure was indicated as the largest variance explained by any individual factor was $41.7 \%$. Hence, no CMB was reported in this study, which might have confounded the interpretation of the results.

\section{Results}

\section{Profile of respondents}

In this study, three factors were used to measure the individual characteristics of the teachers. These include age, gender and seniority. $78 \%$ of teachers were between ages 25-35 years. The gender composition of the sample was almost $71 \%$ females and $29 \%$ males. This slightly skewed result reflects the typical setup of schools in Pakistan whereby females account for majority of careers in teaching. More than half of the teachers had seniority of more than 5 years with the same organization. From the works of Brown \&Treviño(2006),Kalshoven\& Boon (2012), age and gender of employees did not have any correlation with leader's ethical behavior. However, seniority of the employees (Ko et al., 2018) can influence the responses since ethical leadership can be reasonably assessed by an employee who knows him/ her well for a significant period of time. So, seniority was accounted for as a control variable. 


\section{Descriptive Statistics}

The table 2 shows the descriptive statistics, reliability and the correlations among the variables. All the variables showed reliable results. All the variables had significant correlations with each other. The impact of seniority was also checked along with as age and gender had been established to have no impact.

Table 2: Correlations, Mean, Standard Deviation (SD), Average Variance Extracted (AVE), Composite Reliability $(C R)$.

\begin{tabular}{lllllllc}
\hline Constructs & 1 & 2 & 3 & Mean & S.D & CR & AVE \\
\hline 1. Ethical leadership & 1 & $0.585^{* *}$ & $0.431^{* *}$ & 3.83 & 0.14 & 0.925 & 0.82 \\
2. Teacher commitment & $0.585^{* *}$ & 1 & $0.54^{* *}$ & 3.04 & 0.36 & 0.948 & 0.67 \\
3. Seniority & $0.431^{* *}$ & $0.54^{* *}$ & 1 & - & 0.52 & 0.899 & 0.83 \\
\hline & & & & & & & \\
\hline
\end{tabular}

\section{Correlations}

The correlation between ethical leadership and teacher commitment is $58.5 \%$, which is a moderately strong correlation, supporting the hypothesis 1. Also from the table 1 , the value of mean indicates that the teachers perceived the ethical leadership behaviors as moderate. With this, research questions 2 and 3 are answered. The results conclude that ethical leadership is positively related to the teacher commitment and hypothesis 1 is supported.

\section{Factor and Reliability Analysis}

Although ELQ scale has been validated in the study of Yukl et al., (2013) for population comprising of different industries e.g., aerospace, software and telecommunications, banking and government sector, however in order to see whether this scale provides consistent results in education sector, Exploratory and Confirmatory factor analysis were done to check the Discriminant validity. Further, reliability of the scale was checked and the scale was found to be highly reliable with value of Cronbach's alpha more 
than 0.7 (as shown in table 2). The data was found suitable for factor analysis as KMO value was 0.817 (more than 0.7 ) and Bartlett's sphericity test was significant at 0.05. EFA used Principal Component Analysis (PCA) and Varimax Rotation methods which yielded four factors that accounted for $66 \%$ of the total variance explained.

\section{Measurement model and CFA}

Before the research model and the hypotheses, the validity of measurement model was assessed using Confirmatory Factor Analysis (CFA) with SEM using AMOS. The basic measurement model consists of two variables: ethical leadership and teacher. The two factor measurement model and the structural data analysis revealed good fit with the values of $(\mathrm{CMIN} / \mathrm{df}=2.72, \mathrm{GFI}=0.88, \mathrm{CFI}=0.96, \mathrm{IFI}=0.941, \mathrm{RMSEA}=0.056)$. The values of standardized factor loadings were found to be more than 0.6 with $\mathrm{p}<0.01$, hence convergent validity was established as shown in table 3 . The scale was proved valid for sample in educational sector. With this, research question 1 is answered.

Table 3. Results of CFA for measurement model

Constructs and items

StandardizedLoading

Ethical leadership $(\alpha=0.927)$

1. My boss shows a strong concern for ethical and moral values

0.728

2. My boss communicates clear ethical standards for members

0.831

3. My boss sets an example of ethical behavior in his/her 0.876 decisions and actions

4. My boss is honest and can be trusted to tell the truth

5. My boss keeps his/her actions consistent with his/her stated 0.741 values ("walks the talk").

6. My boss is fair and unbiased when assigning tasks to Members

7. My boss can be trusted to carry out promises and commitments 0.786 


\section{IJELM - International Journal Educational Leadership \& Management,}

8. My boss insists on doing what is fair and ethical even when it is not easy

9. My boss acknowledges mistakes and takes responsibility for 0.654 them

10. My boss regards honesty and integrity as important personal values

11. My boss sets an example of dedication and self-sacrifice for the organization

12. My boss opposes the use of unethical practices to increase Performance

13. My boss is fair and objective when evaluating member performance and providing rewards.

14. My boss puts the needs of others above his/her own selfinterest.

15. My boss holds members accountable for using ethical practices in their work

\section{TeacherCommitment $(\alpha=0.808)$}

1. Often, I find it is difficult to agree with this organization's 0.546 policies on important matters relating to its employee

2 I talk up this school to my friend as a great school to work for.

3 I find that my values and my school's values are very similar.

4. All students can succeed and it is my mission to ensure their success.

5. It is my responsibility to ensure good social relations among my students.

6. I feel obliged to mediate among the rival groups of the students.

7. I used to be more ambitious about my work than I am now.

8. Sometimes I lie awake at night thinking ahead to the next day's work.

9. I enjoyteaching. 
10. If I could get a job different from being a teacher and paying the same amount, I would take it.

11. If I could do it all over again, I would not choose to work in the teaching profession.

12. I am disappointed that I ever entered the teaching profession.

13. The best decision that I have ever made was to become a teacher

This data was rechecked in order to establish reliability using advanced reliability measure, like composite reliability. For ensuring the validity of the data, AVE was measured to check the authenticity of the data. As shown in Table 1, the values of Composite reliability and Average variance Extracted were seen to establish reliability of the latent constructs. All the values of CR were more than 0.7 and that of AVE are greater than 0.5 , hence convergent validity was proved. This implies that the data is totally valid and reliable and the measurement model for ethical leadership and teacher commitment were justified in the structural model.

For checking the remaining hypothesis, it is required to see whether ethical leadership is related to the four dimensions of the teacher commitment. Another measurement model with five variables: ethical leadership, commitment to students, commitment to teaching, commitment to school and commitment to profession was made and assessed for model fitness. The value were $(\mathrm{CMIN} / \mathrm{df}=2.65, \mathrm{GFI}=0.862, \mathrm{CFI}=0.956, \mathrm{IFI}=$ 0.958 , RMSEA $=0.069$ ), which indicate good fitness of the model as these values are within the threshold limits. Also for checking this relationship, the result was further confirmed using MANOVA. This test was used because there is one IV and 4 DVs in the model now. The f- value showed significant results as the $\mathrm{p}$ - value was less than 0.05 for the variables of commitment to teaching and commitment to profession. The following estimates of the $\beta$ and $\mathrm{t}$ - values show relationships ranging from weak to moderate and the $\mathrm{t}$ value for $\mathrm{H} 1, \mathrm{H} 3$ and $\mathrm{H} 5$ are more than 2, confirming the $\mathrm{t} 2$ rule of thumb and are significant. This indicates that ethical leadership influences the variable of teacher commitment by having an impact on the dimensions of 
commitment to profession and teaching. This way, hypotheses 3 and 5 are supported.

\section{Table4.Standardized structural estimates}

\begin{tabular}{|c|c|c|c|}
\hline Path & & $\begin{array}{l}\text { Standardized } \\
\text { Estimates }\end{array}$ & t- value \\
\hline H1: Ethical leadership $\longrightarrow$ & Teacher Commitment & $\mathbf{0 . 5 8 5}$ & 12.46 \\
\hline H2: Ethical leadership $\longrightarrow$ & Commitment to Students & 0.114 & 1.91 \\
\hline H3: Ethical leadership $\longrightarrow$ & Commitment to Teaching & 0.363 & 8.26 \\
\hline H4: Ethical leadership $\longrightarrow$ & Commitment to School & 0.174 & 1.77 \\
\hline H5: Ethical leadership $\longrightarrow$ & Commitment to Profession & 0.462 & 10.02 \\
\hline
\end{tabular}

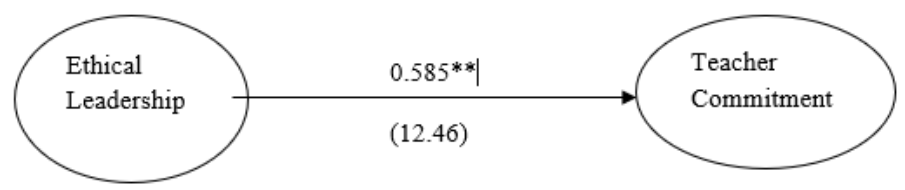

Figure 1. Model 1. Estimates of SEM. T-value, solid line: significant path, $* * p<0.01, * p<0.05$

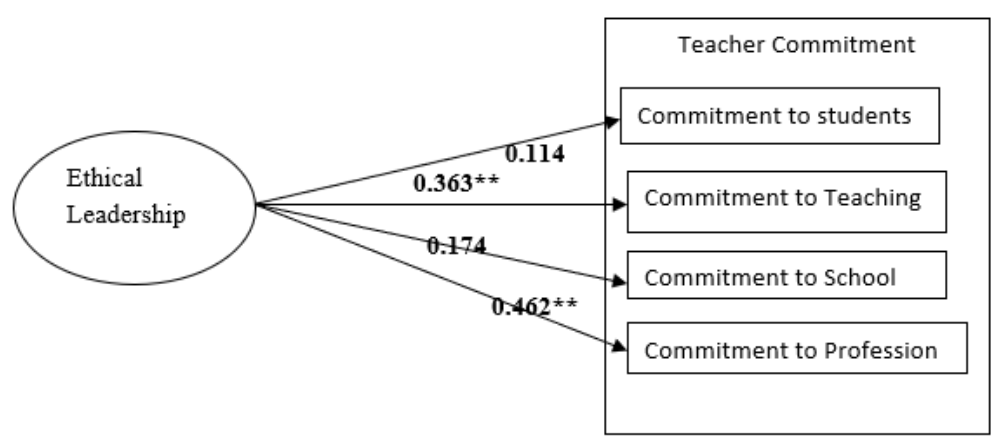

Figure 2.Model 2 Estimates of SEM. $t$-value, solid line: significant path, $* * p<0.01, * p<0.05$. 


\section{Discussion and Conclusion}

The main purpose of this study was to validate the ELQ scale for leaders in educational sector of Pakistan and to determine the perceptions of ethical leadership behavior from the stand point of teachers and examine the possible linkage of ethical leadership and commitment of the school teachers and its dimensions. The results of the study show that ELQ is a valid instrument for investigating the perceptions of teachers regarding the ethical behavior of school leaders in Pakistan and this behavior has positive effect on teacher commitment, who perceived it at a moderate level. Also, it was proved that unlike age and gender, the longer the tenure of the employees, more ethical they will perceive the behavior of leader. Hence, it can be concluded that leaders with ethical behavior skills tend to inspire their followers since leaders are observed closely for both positive and negative traits and are modeled for positive ones like honesty and transparency. Organizations can survive in dynamic world of business when their leaders themselves take the responsibility of being ethical in their practices to influence their followers. According to Rowe \& Guerrero (2012) "ethics is in the heart of leadership at school".

This study adds contribution to theory by investigating the link between ethical leadership behavior and organizational commitment of teachers by conceptualizing it as "teacher commitment" specifically to measure the commitment of teachers. Another contribution is that this study assessed the validity of ELQ scale for school leaders in Pakistan. Practically, this study is of immense importance to the school administrators and leaders since it sets up an example of role model in front of teachers and students who can later serve as effective ethical leaders. In addition to this, the ethical leadership behaviors can contribute to positive employee outcomes like commitment of teachers which can lead to achievement of school and educational goals. 


\section{Limitations and Directions for future research}

This study suffers from a few limitations regarding the demography of the sample. The sample was selected from schools of Multan and Bahawalpur regions, this avenue could be expanded to other bigger cities of Pakistan like Lahore and Islamabad. Also the sample size could be increased for further generalization of the result. Another limitation is the possibility of respondent bias even after assuring complete anonymity and confidentiality. A qualitative analysis of the same model can shed light on more underlying variables that might affect or are affected by them, hereby increasing the validity of the study. Future studies must address the underlying mechanism in this relationship by investigating other variables as mediators. Also, effect of the school climate or school culture can be checked as a moderating variable. The scope of future study can be extended by increasing sample size, investigating the research framework for different nations or conducting a qualitative survey.

\section{References}

Agha, N. C., Nwekpa, K. C., \& Eze, O. R. (2017). Impact of ethical leadership on employee commitment in Nigeria-a study of Innoson Technical and Industrial Company Limited Enugu, Nigeria. International Journal of Development and Management Review, 12(1), 202-214.

Allen, N. J., \& Meyer, J. P. (1996). Affective, continuance, and normative commitment to the organization: An examination of construct validity. Journal of Vocational Behavior, 49(3), 252-276.

Asif, M., Qing, M., Hwang, J., \& Shi, H. (2019). Ethical leadership, affective commitment, work engagement, and creativity: Testing a multiple mediation approach. Sustainability, 11(16), 4489.

Bai, Y., Lin, L., \& Liu, J. T. (2019). Leveraging the employee voice: a multi-level social learning perspective of ethical leadership. The International Journal of Human Resource Management, 30(12), 1869-1901. 
Bandura, A., \& Walters, R. H. (1977). Social learning theory (Vol. 1): Prentice-hall Englewood Cliffs, NJ.

Bedi, A., Alpaslan, C. M., \& Green, S. (2016). A meta-analytic review of ethical leadership outcomes and moderators. Journal of Business Ethics, 139(3), 517-536.

Blau, P. (1964). Power and exchange in social life: New York: J Wiley \& Sons.

Bolat, T., \& Seymen, O. A. (2003). ÖRGÜTLERDE İŞ ET iĞININ YERLESTTİIILMESINDE" DÖNÜȘÜMCÜ LİDERLİK TARZI" NIN ETKİLERI ÜZERINE BİR DEĞERLENDİRME. Balıkesir Üniversitesi Sosyal Bilimler Enstitüsü Dergisi, 6(9), 59-85.

Brown, M. E., \& Treviño, L. K. (2006). Ethical leadership: A review and future directions. The leadership quarterly, 17(6), 595-616.

Byza, O. A., Dörr, S. L., Schuh, S. C., \& Maier, G. W. (2019). When leaders and followers match: the impact of objective value congruence, value extremity, and empowerment on employee commitment and job satisfaction. Journal of Business Ethics, 158(4), 1097-1112.

Campbell, R., Kyriakides, L., Muijs, R., \& Robinson, W. (2004). Effective teaching and values: Some implications for research and teacher appraisal. Oxford Review of Education, 30(4), 451-465.

Celep, C. (2000). Teachers' Organizational Commitment in Educational Organizations. Paper presented at the National Forum of Teacher Education Journal.

Celik, V. (2000). Egitimsel liderlik [Educational leadership]. Ankara: Pegem A.

Crosswell, L. (2006). Understanding teacher commitment in times of change. Queensland University of Technology.

Daniëls, E., Hondeghem, A., \& Dochy, F. (2019). A review on leadership and leadership development in educational settings. Educational Research Review.

De Hoogh, A. H., \& Den Hartog, D. N. (2008). Ethical and despotic leadership, relationships with leader's social responsibility, top management team effectiveness and subordinates' optimism: A multi-method study. The leadership quarterly, 19(3), 297-311.

Grace, B., \& Grace, W. J. (1998). Ethical leadership: In pursuit of the common good (Vol. 1): CEL publications. 
Hassan, S., Mahsud, R., Yukl, G., \& Prussia, G. E. (2013). Ethical and empowering leadership and leader effectiveness. Journal of Managerial Psychology.

Haynes, F. (2002). The ethical school: consequences, consistency and caring: Routledge.

Hendri, N. (2019). The impact of organizational commitment on job performance.

Kalshoven, K., \& Boon, C. T. (2012). Ethical leadership, employee wellbeing, and helping. Journal of Personnel Psychology.

Kalshoven, K., Den Hartog, D. N., \& De Hoogh, A. H. (2011). Ethical leadership at work questionnaire (ELW): Development and validation of a multidimensional measure. The leadership quarterly, 22(1), 51-69.

Kanungo, R. N., \& Mendonca, M. (2001). Ethical leadership and governance in organizations: A preamble. Canadian Journal of Administrative Sciences, 18(4), 241.

Kim, M.-S., \& Thapa, B. (2018). Relationship of ethical leadership, corporate social responsibility and organizational performance. Sustainability, 10(2), 447.

Ko, C., Ma, J., Bartnik, R., Haney, M. H., \& Kang, M. (2018). Ethical leadership: An integrative review and future research agenda. Ethics \& Behavior, 28(2), 104-132.

Louis, K. S. (1998). Effects of teacher quality of work life in secondary schools on commitment and sense of efficacy. School effectiveness and school improvement, 9(1), 1-27.

Lynch, M. (2015). The eight principles of ethical leadership in education. The Edvocate.

Mayer, D. M., Kuenzi, M., Greenbaum, R., Bardes, M., \& Salvador, R. B. (2009). How low does ethical leadership flow? Test of a trickledown model. Organizational behavior and human decision processes, 108(1), 1-13.

Meyer, J. P., \& Allen, N. J. (1984). Testing the" side-bet theory" of organizational commitment: Some methodological considerations. Journal of applied psychology, 69(3), 372.

Nir, A. E. (2002). School-based management and its effect on teacher commitment. International Journal of Leadership in Education, 5(4), 323-341. 
Özan, M. B., Özdemir, T. Y., \& Yirci, R. (2017). Ethical leadership behaviours of school administrators from teachers' point of view. Foro de Educación, 15(23), 161-184.

Porter, L., Mowday, R., \& Steers, R. (1979). The measurement of organizational commitment. Journal of Vocational Behavior, 14(2), 224-247.

Powell, D. M., \& Meyer, J. P. (2004). Side-bet theory and the threecomponent model of organizational commitment. Journal of Vocational Behavior, 65(1), 157-177.

Qing, M., Asif, M., Hussain, A., \& Jameel, A. (2019). Exploring the impact of ethical leadership on job satisfaction and organizational commitment in public sector organizations: The mediating role of psychological empowerment. Review of Managerial Science, 1-28.

Resick, C. J., Hanges, P. J., Dickson, M. W., \& Mitchelson, J. K. (2006). A cross-cultural examination of the endorsement of ethical leadership. Journal of Business Ethics, 63(4), 345-359.

Riggio, R. E., Zhu, W., Reina, C., \& Maroosis, J. A. (2010). Virtue-based measurement of ethical leadership: The Leadership Virtues Questionnaire. Consulting Psychology Journal: Practice and Research, 62(4), 235.

Rowe, W. G., \& Guerrero, L. (2012). Cases in leadership: Sage.

Sabir, S., \& Bhutta, Z. M. (2018). Leader motivating language as predictor of organizational commitment among generation $\mathrm{Y}$ teachers: The mediating role of organizational climate. NUML International Journal of Business \& Management, 13(1), 118-133.

Shao, P. (2010). Ethics-based leadership and employee ethical behavior: Examining the mediating role of ethical regulatory focus.

Simola, S., Barling, J., \& Turner, N. (2012). Transformational leadership and leaders' mode of care reasoning. Journal of Business Ethics, 108(2), 229-237.

Singh, K., \& Billingsley, B. S. (1998). Professional support and its effects on teachers' commitment. The journal of educational research, 91(4), 229-239.

Somech, A., \& Bogler, R. (2002). Antecedents and consequences of teacher organizational and professional commitment. Educational administration quarterly, 38(4), 555-577. 
Tarter, C. J. (1989). Principal Leadership and Organizational Commitment: The Principal Must Deliver. Planning and changing, 20(3), 131-140. Thien, L. M., Razak, N. A., \& Ramayah, T. (2014). Validating teacher commitment scale using a Malaysian sample. SAGE Open, 4(2), 2158244014536744.

Treviño, L. K., Brown, M., \& Hartman, L. P. (2003). A qualitative investigation of perceived executive ethical leadership: Perceptions from inside and outside the executive suite. Human relations, 56(1), 5-37.

Tsui, K. T., \& Cheng, Y. C. (1999). School organizational health and teacher commitment: A contingency study with multi-level analysis. Educational Research and Evaluation, 5(3), 249-268.

Yukl, G., Mahsud, R., Hassan, S., \& Prussia, G. E. (2013). An improved measure of ethical leadership. Journal of leadership \& organizational studies, 20(1), 38-48.

Sara Sabir is teaching at University of Education, Multan campus in Pakistan. In addition to this, she has taught various courses in other business schools. Her keen interests in research include Leadership, Leader language, HRM and Organization behavior.

Contact Address: 16- E, Officers Colony, Bosan Road, Multan, Pakistan

E-mail: saraomairbucha@ gmail.com 